\title{
A set of novel microsatellite markers developed for an economically important tree, Dracontomelon duperreanum, in China
}

\author{
Z.F. Wang, H.L. Cao, L.F. Wu, Y. Guo, Q.M. Mei, M. Li, Y. Wang and \\ Z.M. Wang \\ Guangdong Provincial Key Laboratory of Applied Botany \& Key Laboratory \\ of Vegetation Restoration and Management of Degraded Ecosystems, \\ South China Botanical Garden, Chinese Academy of Sciences, \\ Guangzhou, China \\ Corresponding author: H.L. Cao \\ E-mail: caohl@scib.ac.cn \\ Genet. Mol. Res. 16 (2): gmr16029578 \\ Received December 12, 2016 \\ Accepted March 21, 2017 \\ Published May 10, 2017 \\ DOI http://dx.doi.org/10.4238/gmr16029578
}

Copyright $(2017$ The Authors. This is an open-access article distributed under the terms of the Creative Commons Attribution ShareAlike (CC BY-SA) 4.0 License.

ABSTRACT. Dracontomelon duperreanum, the most representative
species of the family Anacardiaceae, is an important multipurpose tree
in China and Vietnam. However, no genetic diversity studies have been
reported on this species. In this study, we identified 11 microsatellite
markers for D. duperreanum by using the restriction-site-associated
DNA sequencing (RAD-seq) method and examined their polymorphisms
in 22 samples obtained from the South China Botanical Garden, South
China. We could detect only two or three alleles for each microsatellite
marker. The mean observed and expected heterozygosities were 0.41
and 0.39 , respectively, which were lower than those reported for the
species with similar life history forms. These relatively low genetic
diversities in this common plant species are unexpected and might
have resulted from its extensive cultivation. To our knowledge, this is
the first report of microsatellite markers in the genus Dracontomelon.
These microsatellite markers will be valuable for studying the genetic

Genetics and Molecular Research 16 (2): gmr16029578 
diversities and structures in D. duperreanum and other Dracontomelon species.

Key words: Dracontomelon duperreanum; Genetic diversity; Microsatellite marker development; Polymorphism; Restriction-site-associated DNA sequencing; Subtropical China

\section{INTRODUCTION}

Dracontomelon duperreanum, a broad-leaved evergreen tree, belongs to the family Anacardiaceae. It is naturally distributed in South China and Vietnam (Zheng and Ming, 1980). Because the surface of its seed shows some characters like a human face, it is called "Ren Mian Zi" meaning human face, in China (Yu, 1987) (Figure 1).
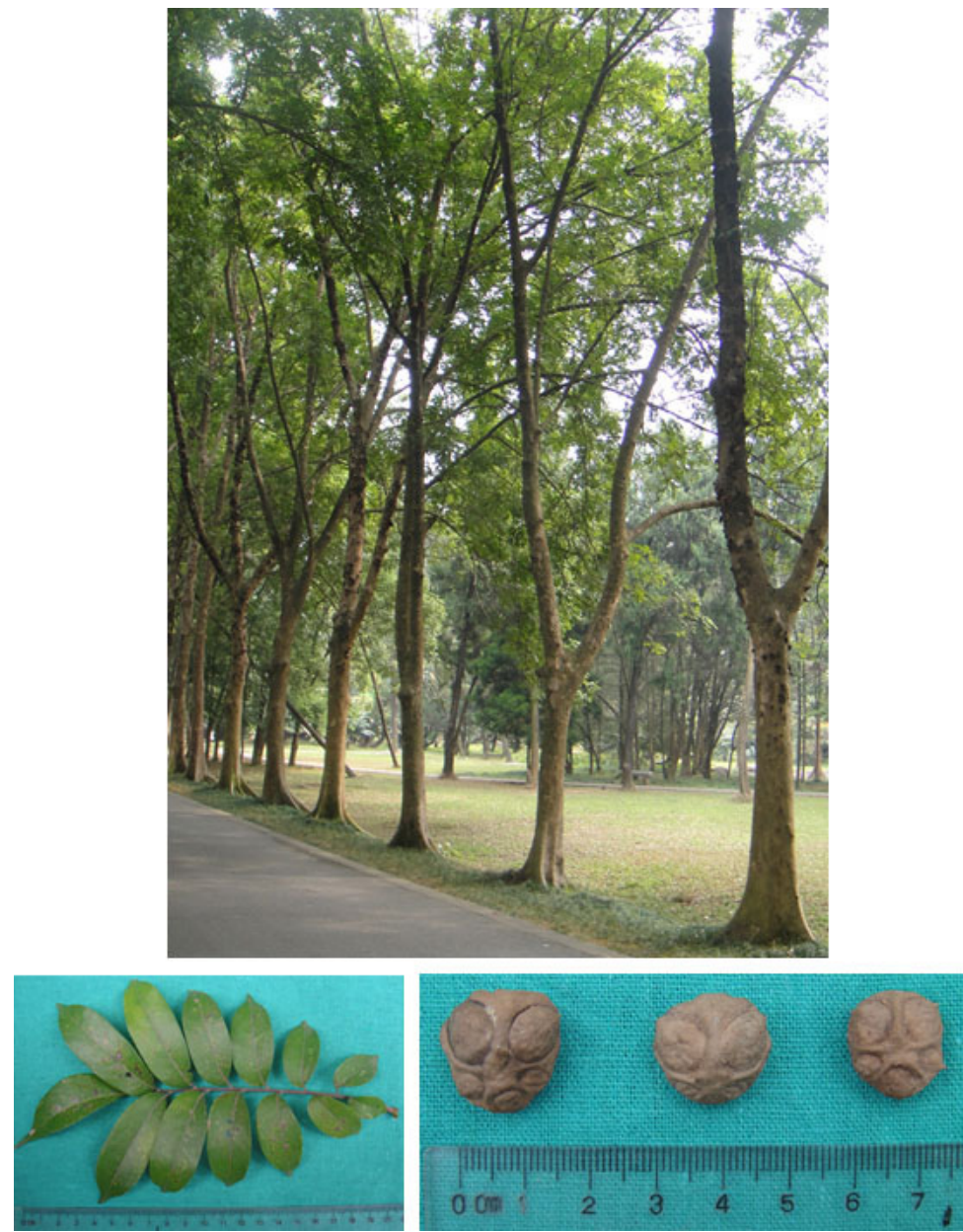

Figure 1. Pictures showing the trees, leaves and seeds of Dracontomelon duperreanum planted in the South China Botanical Garden, Guangzhou, China.

Genetics and Molecular Research 16 (2): gmr16029578 
Dracontomelon duperreanum is an important multipurpose tree. It grows in different kinds of soil and can tolerate low temperatures (Zhou et al., 2008). It has a straight trunk with strong buttresses and can grow up to 20-m tall (Xiao and Feng, 2014). Its crowns are dense and spreading (Zhang and Ma, 2005). It is seldom attacked by insects and diseases and stands strong in the winds and polluted air ( $\mathrm{Lu}$ et al., 2005). All these features make it suitable for planting in gardens and along streets (Yu, 1987; Xiao and Feng, 2014). It has been reported that $D$. duperreanum can be a host species of Santalum album, a famous aromatic tree native to southern China ( $\mathrm{Lu}$ et al., 2014). Its fruits are edible and can be eaten raw or preserved as jams and conserves (Wang et al., 2016b). Its seed oil can be used for making soap or lubricating oil (Luo and Liu, 2007). Its wood is dense, lustrous, corrosion-resistant, and odor-free, and therefore suitable for making furniture. It is also a Chinese traditional medicinal plant (Liang, 1988; Zhang and Ma, 2005). Its fruits, barks, roots, and leaves can be used as medicine to strengthen stomach, relieve pain, and promote wound healing (Su et al., 2008). Its bark contains flavonoids (Weng et al., 2016), which have been recently confirmed to have anticancer activity (Chahar et al., 2011). Its leaf extracts contain many antimicrobial components, such as petroleum ether, chloroform, ethyl acetate, and n-butanol, which act against Staphylococcus aureus, Escherichia coli, and Bacillus subtilis (Su and Nong, 2010). In addition, its leaf extracts can inhibit the activity of Microcystis aeruginosa, an algal species that causes harmful algal blooms (Wang et al., 2016a). However, in the natural environment, owing to the low content of polyphenols in its leaves, its litters can be easily decomposed, supporting material cycling and energy flow in the ecosystem (Yan et al., 2007; Guan et al., 2008).

Genetic diversity is the amount of variation in the heritable material maintained within and among species; it represents the adaptive and evolutionary potential of a species and has great economic, environmental, and scientific values (Loo et al., 2014). However, no genetic diversities have been reported for this valuable multipurpose tree yet, and such information is necessary for the efficient management of its genetic resources. Therefore, in this study, we developed a set of microsatellite markers that can be used to study the genetic diversities and population structures of this economically important species.

\section{MATERIAL AND METHODS}

Mature leaves of two trees, one from Dinghushan Natural Reserve (DHS) and the other from the South China Botanical Garden (SCBG), were collected and put in liquid nitrogen immediately. These two sampling sites are located in Guangdong province of South China. Subsequently, DNA was extracted from one leaf of each sample using a modified cetyl trimethylammonium bromide (CTAB) method (Doyle, 1991) and dissolved in $50 \mu \mathrm{L}$ (Tris-EDTA) TE solution. The concentration and quality of DNA were assessed using Agilent 2100 Bioanalyzer (Agilent Technologies, Santa Clara, CA, USA). Each DNA sample was then diluted to a final concentration of $50 \mathrm{ng} / \mu \mathrm{L}$, and stored at $-20^{\circ} \mathrm{C}$ until further use. The restriction-site-associated DNA sequencing (RAD-seq) libraries for these two DNA samples were constructed using $300 \mathrm{ng}$ of each DNA sample and subsequently subjected to DNA sequencing using a HiSeq2500 sequencer (Illumina, Inc., San Diego, CA, USA). After trimming adapters and removing polymerase chain reaction (PCR) duplicates, we obtained $31,418,522$ and 22,947,686 clean sequences for DHS and SCBG samples, respectively. By further removing the low-quality sequences, we assembled the remaining sequences using the software STACK 1.24 (Catchen et al., 2011; Catchen et al., 2013). For the assembled

Genetics and Molecular Research 16 (2): gmr16029578 
sequences, we used MSATCOMMANDER 0.8.2 (Faircloth, 2008) to identify the dinucleotide and trinucleotide motifs with a minimum of nine and eight repeats, of which 49 could be used to design primers.

To test the availability of these microsatellite loci, we initially used one individual from SCBG to conduct PCR amplification. For each microsatellite locus, PCR was then carried out in a $20-\mu \mathrm{L}$ reaction mixture containing $50 \mathrm{ng}$ template DNA, $2 \mu \mathrm{L} 10 \mathrm{X}$ PCR Buffer ( $\mathrm{Mg}^{2+}$ plus), $0.4 \mu \mathrm{L} 10 \mathrm{mM}$ dNTPs, $1 \mu \mathrm{L}$ forward and reverse primers $(5 \mu \mathrm{M})$, and 1 U Taq DNA polymerase (Takara Biotechnology Co., Ltd., Dalian, Liaoning, China). PCR amplification was programmed for initial denaturation at $95^{\circ} \mathrm{C}$ for $5 \mathrm{~min}$, followed by 35 cycles of denaturation at $94^{\circ} \mathrm{C}$ for $30 \mathrm{~s}$, annealing at $55^{\circ} \mathrm{C}$ for $30 \mathrm{~s}$, and extension at $72^{\circ} \mathrm{C}$ for $45 \mathrm{~s}$, and a final extension at $72^{\circ} \mathrm{C}$ for $10 \mathrm{~min}$. Amplified products were electrophoretically separated using $2 \%$ agarose gels. Thirty-seven microsatellite loci gave successful results of the target regions. Because all loci performed well at the annealing temperature of $55^{\circ} \mathrm{C}$, we did not optimize them further to reduce the experimental cost. These loci were then used to examine their polymorphisms in 22 individuals from SCBG. Unlike the samples used for RAD-seq library constructions, the samples collected from these trees were put into the sealed bags containing silica gels, but they were subjected to the same DNA extraction, assessment, and storage procedures. Their PCR amplification products were electrophoretically separated on ABI 3730 sequencer (Applied Biosystems, Carlsbad, CA, USA), and their product sizes were determined using the ABI GeneMapper Software 4.1. Finally, eleven microsatellites showed stable and clear polymorphism.

The genetic diversity of these microsatellite loci was computed in GENEPOP 4.3 (Rousset, 2008). We also used this software to assess the deviation from Hardy-Weinberg equilibrium (HWE) and genotypic linkage disequilibrium (LD) among all pairs of loci. The levels of significance for HWE and LD tests were adjusted by using the sequential Bonferroni correction (Holm, 1979).

\section{RESULTS AND DISCUSSION}

The number of alleles per locus varied from two to three (Table 1). The $H_{\mathrm{O}}$ and $H_{\mathrm{E}}$ values varied from 0.105 to 0.800 and from 0.102 to 0.663 , respectively. No locus exhibited significant departure from HWE. Significant LD was found in only five locus pairs without Bonferroni correction and in three loci pairs (RMZ-8 with RMZ-1, RMZ-25, and RMZ-45) after Bonferroni correction.

Using the same RAD-seq method, we obtained 63 polymorphic loci from 170 candidate loci (37.1\%) in an endangered species, Bretschneidera sinensis, in a previous study ( $\mathrm{Li}$ et al., 2016), but we could obtain only 11 polymorphic loci among the 49 loci $(29.7 \%)$ identified in this study. In addition, the highest number of alleles per locus was three in $D$. duperreanum and 16 in $B$. sinensis with 30 samples from one population. In $B$. sinensis, we found that 37 loci had more than three alleles each, and five loci had more than 10 alleles each. Because $D$. duperreanum is a common and widely distributed species in South China, such small number of alleles was unexpected.

Low genetic diversity in $D$. duperreanum was further confirmed when we compared its genetic diversity with the genetic diversities of other species with similar life history forms. According to Nybom (2004), the mean $H_{\mathrm{O}}$ and $H_{\mathrm{E}}$ were 0.63 and 0.68 for long-lived perennials, 0.65 and 0.65 for regionally distributed species, 0.63 and 0.65 for outcrossing

Genetics and Molecular Research 16 (2): gmr16029578 
Table 1. Characteristics of 11 microsatellite markers in Dracontomelon duperreanum. Annealing temperature for all loci is $55^{\circ} \mathrm{C}$. Forward primers for all loci are labeled with 6-fluorescein amidite (FAM).

\begin{tabular}{|c|c|c|c|c|c|c|c|c|}
\hline Locus & $\begin{array}{l}\text { Repeat motifs of individual applied } \\
\text { to RAD sequencing }\end{array}$ & Primer sequences $\left(5^{\prime} \rightarrow 3^{\prime}\right)$ & Size range (bp) & $A$ & $H_{\mathrm{O}}$ & $H_{\mathrm{E}}$ & $F$ & $\begin{array}{l}\text { EMBL/GenBank } \\
\text { accession No.* }\end{array}$ \\
\hline RMZ-1 & (CT) 9 & $\begin{array}{l}\text { F: TCAGTAACTAATGTTCTCCACAAG } \\
\text { R: ACTAGACCAATAGGCATGTCTTC }\end{array}$ & $217-233$ & 3 & 0.800 & 0.569 & -0.4206 & LT671604 \\
\hline RMZ-2 & $(\mathrm{AT})_{11}$ & $\begin{array}{l}\text { F: TGGCTTAGCTCTAACGGCTC } \\
\text { R: TCCAATGCTCACAGTGCTATC }\end{array}$ & $229-233$ & 2 & 0.150 & 0.142 & -0.0556 & LT671605 \\
\hline RMZ-8 & (ATT)9 & $\begin{array}{l}\text { F: ATCCTACAAATGCATCTCAGTTC } \\
\text { R: GGGATGAGAGGGTCAAGGC }\end{array}$ & $157-160$ & 2 & 0.318 & 0.460 & 0.3131 & LT671606 \\
\hline RMZ-12 & (CT) 10 & $\begin{array}{l}\text { F: GCGTGCCCGAAGAAACTC } \\
\text { R: TTCCCTTGTGCATAAACGTG }\end{array}$ & $261-263$ & 2 & 0.474 & 0.422 & -0.1250 & LT671607 \\
\hline RMZ-25 & $(\mathrm{TA}) 9$ & $\begin{array}{l}\text { F: GGCTCAGCATACTTTGGGAC } \\
\text { R: GATTCCGGAGCCATACTGC }\end{array}$ & $152-154$ & 2 & 0.150 & 0.358 & 0.5870 & LT671609 \\
\hline RMZ-28 & $(\mathrm{AG})_{10}$ & $\begin{array}{l}\text { F: TGAAACCCTTTAGAGTATGCTTG } \\
\text { R: GGACATCTTGCTTGGAGGC }\end{array}$ & $184-186$ & 2 & 0.300 & 0.663 & -0.1515 & LT671611 \\
\hline RMZ-29 & $(\mathrm{AG})_{12}$ & $\begin{array}{l}\text { F: ACTCACCTATTTCCTTGGCTG } \\
\text { R: GAGCGGGAAGCCTTAGACC }\end{array}$ & $209-227$ & 2 & 0.105 & 0.102 & -0.0286 & LT671612 \\
\hline RMZ-33 & $(\mathrm{AT}) 9$ & $\begin{array}{l}\text { F: AATTCATCCACGCAACGGG } \\
\text { R: GGCAAATGTGAATGCTCACG }\end{array}$ & $211-213$ & 2 & 0.650 & 0.481 & -0.3646 & LT671613 \\
\hline $\begin{array}{l}\text { RMZ-45 } \\
\text { R }\end{array}$ & $(\mathrm{CA})_{13}$ & $\begin{array}{l}\text { F: CGTCATTGAGGACACTAGACC } \\
\text { R: TGGTACTTGGGATGAAACTTAGG }\end{array}$ & $185-187$ & 2 & 0.400 & 0.492 & 0.1915 & LT671614 \\
\hline RMZ-46 & $(\mathrm{TA})_{10}$ & $\begin{array}{l}\text { F: TCGCAATTGTTTCTGAAGGG } \\
\text { R: TCATGGGATGAATTGGTGGC }\end{array}$ & $159-177$ & 3 & 0.316 & 0.383 & 0.1787 & KY304004 \\
\hline $\begin{array}{l}\text { RMZ-48 } \\
\text { n }\end{array}$ & $(\mathrm{AT}))_{13}$ & $\begin{array}{l}\text { F: GGAGGGTGAAAGCTACTAATGTTC } \\
\text { R: GCCATTAGCTGCTTCCTCG }\end{array}$ & $201-205$ & 2 & 0.600 & 0.431 & -0.4074 & LT671615 \\
\hline
\end{tabular}

$A$ : number of alleles; $H_{\mathrm{O}}$ : observed heterozygosity; $H_{\mathrm{E}}$ : unbiased expected heterozygosity; $F$ : fixation index; RAD sequencing: Restriction site-associated DNA sequencing; EMBL: European Molecular Biology Laboratory. *Full sequence information will be released on June 15, 2017.

species, and 0.50 and 0.47 for species with gravity seed-dispersal, respectively. These values were higher than the $H_{\mathrm{O}}(0.41)$ and $H_{\mathrm{E}}(0.39)$ values obtained for $D$. duperreanum in this study. One possible reason for the low genetic diversity in $D$. duperreanum might be that the samples we studied were obtained from the South China Botanical Garden, and they might have been obtained from some cultivated resources harboring low genetic diversity. A deficiency of genetic variation in cultivated plant is a common phenomenon due to modern plant breeding (Ahuja and Jain, 2015). However, further studies are necessary to investigate if the genetic diversities in the wild $D$. duperreanum populations are also low.

To the best of our knowledge, this is the first report of the development of microsatellite markers in the genus Dracontomelon. These markers will be valuable for studying the genetic diversities and structures in D. duperreanum and other Dracontomelon species.

\section{Conflicts of interest}

The authors declare no conflict of interest.

\section{ACKNOWLEDGMENTS}

Research supported by the Special Foundation for Forestry Science and Technology Innovation project in Guangdong Province (\#2013KJCX001-08), China.

\section{REFERENCES}

Ahuja MR and Jain SM (2015). Genetic diversity and erosion in plants: Indicators and prevention. Springer International Publishing AG, Switzerland.

Catchen JM, Amores A, Hohenlohe P, Cresko W, et al. (2011). Stacks: building and genotyping Loci de novo from shortread sequences. G3 (Bethesda) 1: 171-182. http://dx.doi.org/10.1534/g3.111.000240

Catchen J, Hohenlohe PA, Bassham S, Amores A, et al. (2013). Stacks: an analysis tool set for population genomics. Mol. Ecol. 22: 3124-3140. http://dx.doi.org/10.1111/mec.12354

Genetics and Molecular Research 16 (2): gmr16029578 
Chahar MK, Sharma N, Dobhal MP and Joshi YC (2011). Flavonoids: A versatile source of anticancer drugs. Pharmacogn. Rev. 5: 1-12. http://dx.doi.org/10.4103/0973-7847.79093

Doyle JJ (1991). DNA protocols for plants - CTAB total DNA isolation. In: Molecular techniques in taxonomy (Hewitt GM and Johnston A, eds.). Springer-Verlag, Berlin, Germany, 283-293.

Faircloth BC (2008). msatcommander: detection of microsatellite repeat arrays and automated, locus-specific primer design. Mol. Ecol. Resour. 8: 92-94. http://dx.doi.org/10.1111/j.1471-8286.2007.01884.x

Guan ZY, Zhao Y and Tong XL (2008). Effect of polyphenol of leaf litter on the leaf breakdown in a subtropical stream. Ecol. Sci. 27: 436-438.

Holm S (1979). A simple sequentially rejective multiple test procedure. Scand. J. Stat. 6: 65-70.

Li M, Chen HF, Wang ZF and Zhang S (2016). Isolation and characterization of polymorphic microsatellite markers in the endangered species Bretschneidera sinensis Hemsl. Genet. Mol. Res. 15: 10.4238/gmr.15038234.

Liang XD (1988). Preliminary Study on different kinds of drugs in Guangxi Zhuang Nationality region in Qin and Han dynasties. Guangxi Ethnics Studies 4: 136-142.

Loo J, Souvannavong O and Dawson IK (2014). Seeing the trees as well as the forest: The importance of managing forest genetic resources. For. Ecol. Manage. 333: 1-8. http://dx.doi.org/10.1016/j.foreco.2014.08.014

Lu JK, Xu DP, Kang LH and He XH (2014). Host-species-dependent physiological characteristics of hemiparasite Santalum album in association with N2-fixing and non-N2-fixing hosts native to southern China. Tree Physiol. 34: 1006-1017. http://dx.doi.org/10.1093/treephys/tpu073

Lu YD, Feng CX, Chen HY and Li ZK (2005). Configuration of tree species and classification of defensive seclusion cincture of urban forest in Zhujiang River Delta. J. Chin. Urban For. 3: 34-38.

Luo Y and Liu M (2007). Oil-bearing trees as a source for biodiesel. China Biotechnol. 27: 68-74.

Nybom H (2004). Comparison of different nuclear DNA markers for estimating intraspecific genetic diversity in plants. Mol. Ecol. 13: 1143-1155. http://dx.doi.org/10.1111/j.1365-294X.2004.02141.x

Rousset F (2008). genepop'007: a complete re-implementation of the genepop software for Windows and Linux. Mol. Ecol. Resour. 8: 103-106. http://dx.doi.org/10.1111/j.1471-8286.2007.01931.x

$\mathrm{Su}$ XF and Nong WT (2010). Study on antimicrobial activity of extracts from Dracontomelon duperreanum. China Pharm. 23: 2115-2117.

Su XF, Liang ZY and Nong KL (2008). Study on the chemical components of essential oil from the leaves of Dracontomelon duperreanum. Zhongchengyao 30: 1549-1550.

Wang X, Jiang C, Szeto YT, Li HK, et al. (2016a). Effects of Dracontomelon duperreanum defoliation extract on Microcystis aeruginosa: physiological and morphological aspects. Environ. Sci. Pollut. Res. Int. 23: 8731-8740. http://dx.doi.org/10.1007/s11356-016-6119-1

Wang YS, Chen X and Wang RB (2016b). Geographical distribution pattern of wild fruit tree species in China. Guizhou Agric. Sci. 44: 6-10.

Weng YY, Zhang ZF, Zeng ZF and Su XF (2016). Extraction of total flavonoids from Dracontomelon duperreanum by decompressing inner ebullition. J. Henan Agric. Sci. 45: 148-151.

Xiao JS and Feng JH (2014). Research on the typhoon resistance ability of trees in South China. Chin. Landsc. Archit. 3: 115-119.

Yan L, Zhao Y, Han CX and Tong XL (2007). [Litter decomposition and associated macro-invertebrate functional feeding groups in a third-order stream of northern Guangdong]. Ying Yong Sheng Tai Xue Bao 18: 2573-2579.

Yu H (2008). Propagation techniques of Dracontomelon duperreanum. Mod. Agric. Sci. Technol. 2: 60.

Yu ZM (1987). An ideal tree species for landscape greening-Dracontomelon duperreanum. J. Guangdong Landsc. Archit. 2: 47.

Zhang HW and Ma J (2005). A survey analysis on resources of medicinal plants in Dinghushan National Nature Reserve. Guihaia 25: 539-543.

Zheng M and Ming TL (1980). Flora of China, Tomus 45(1). Science Press, China.

Zhou J, Lan QJ, Tang JH and Lu YC (2008). Investigation of cold damage for tropical and subtropical plants in Guangxi. Trop. Agric. Guangxi 117: 25-29.

Genetics and Molecular Research 16 (2): gmr16029578 